\title{
LONG TERM PRESSURE RECORDINGS UNDER THE ISCHIAL TUBEROSITIES OF TETRAPLEGICS *
}

\author{
By S. V. Fisher, M.D. ${ }^{2}$ and P. Patterson, Ph.D. ${ }^{2}$ \\ ${ }^{1}$ Assistant Professor, Department of Physical Medicine and Rehabiiitation, St Paul- \\ Ramsey Medical Center, St Paul, Minnesota 55IOI. ${ }^{2}$ Director of Research to \\ the Department of Physical Medicine and Rehabilitation, University of Minnesota \\ Hospitals, Minneapolis, Minnesota 55455.
}

Summary. Five ulcer free tetraplegic subjects who are unable to do lift-offs were studied on four separate days on two types of wheelchair cushions to measure the pressures underneath the ischial tuberosities. Small electrical pressure transducers and a tape-recorder were utilised.

The average pressures on the ROHO and foam cushions were $7 \mathrm{I} \cdot 5$ and $105 \cdot 4$ $\mathrm{mmHg}$ respectively. The average time between push-ups greater than I second and greater than 5 seconds was $72 \cdot 1$ and $96 \cdot 2$ minutes. The average pressures and the time between push-ups was greatly in excess of the usually suggested skin care regime. The data would suggest that the relative importance of pressure and pressure relief in the aetiology of decubitus ulcers should be re-examined.

Key words: Spinal cord injury; Decubitus ulcers; Pressure recordings.

\section{Introduction}

IN order to prevent the development of decubitus ulcers it has been suggested that patients with loss of sensation should not remain in any position with pressure above $35 \mathrm{mmHg}$ for periods of time greater than 20-30 minutes without periodically decreasing the pressure by doing a lift-off from their wheelchair. It has been demonstrated that pressures of $70 \mathrm{mmHg}$ for two hours will cause pathological changes in muscle tissue of rats, and pressures of $60 \mathrm{mmHg}$ of one hour duration will cause microscopic changes in the tissue of dogs (Kosiak, I959).

The pressure under the ischial tuberosities of individuals sitting on various seat cushions has been demonstrated in a range of 4 I to $86 \mathrm{mmHg}$ (Mooney et al., I97I; Souther et al., I974). It has been suggested that paraplegics or tetraplegics sitting in wheelchairs relieve their pressure every half hour and every 2 hours they should lie down for approximately i 5 minutes (Griffith, I963). In our institution push-ups of approximately 5 seconds duration every i 5 minutes are suggested.

Many patients fail to perform frequent push-ups even though instructed otherwise. A large number of spinal cord injured patients who remained ulcer free report not doing their own push-ups and not being lifted up or tilted back in their chair during the entire day. A previous study documented frequent lapses in performing suggested pressure relief in a paraplegic population (Patterson \& Fisher, I980).

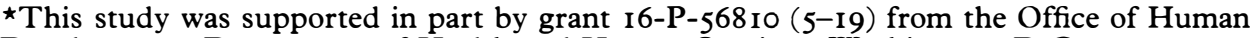
Development, Department of Health and Human Services, Washington, D.C. 
The purpose of this study was to investigate the pressure relief patterns of tetraplegic patients unable to do a lift-off independently in a wheelchair. These subjects were at least one year post injury and with no history of pressure ulcers. To ascertain their push-up behaviour from day to day on two different cushions each subject was studied on four different days as they went about their normal daily activities in their home and work setting. Through this investigation information was obtained about the pressure relief time patterns which do not or had not produced ulcers in tetraplegics as they conducted their usual activities during four separate days.

\section{Methods and Materials}

Five tetraplegics, four males and one female, were studied. All subjects had C6 complete tetraplegia or higher, could partially shift their weight in the wheelchair but did not have triceps function and were unable to perform a lift-off. None of the subjects had a history of an ischial decubitus ulcer or obtained an ulcer within a 6 month period after the study.

The pressures were determined by taping a small ( $\mathrm{I} \mathrm{mm}$ thick by $5 \mathrm{~mm}$ in diameter) Entran model ESP-200 transducer under each ischial tuberosity. The pressure transducers were placed with the patient lying on his side and the hips and knees flexed to 90 degrees. The zero pressure transducer reference point was the pressure measurement determined in the side-lying position with no external force applied. The transducers were applied with double sided tape so that there was no pressure artifact induced by the tape itself. The pressure transducer was applied to the skin overlying the ischial tuberosities and the subjects wore their normal clothing. Each of the transducers were then connected to a small 4 channel Medilog tape recorder which is capable of recording for 24 hours. The pressure transducers were calibrated up to $200 \mathrm{mmHg}$ by placing them in a small pressure chamber reported previously. Patterson and Fisher (I979). The calibration signals were placed on every tape used. It was found that the calibration remained constant over many months. The zero pressure signal was recorded with the pressure transducer on the subject before and after every experiment. The zero baseline used in analysis was a linear interpolation between the starting and ending zero value. The typical drift was approximately $5 \mathrm{mmHg}$. The transducers and tape recorder were applied in the morning and removed in the late afternoon. The subjects were encouraged to go about their normal daily routine. The average experimental time was 5 hours and 30 minutes. Each subject was studied for four days, two days using a 4 inch foam cushion and two days on a ROHO air balloon cushion.

The data were played back using a high speed play back unit with an internal output low pass filter in the $0.5-\mathrm{Hz}$ position as measured in equivalent experimental time. The gain of the system was adjusted to produce a \pm I volt signal for the $o$ to $22 \mathrm{~mm}$ pressure calibration signal. The playback tape speed was servo controlled off a digital timing signal put on the tape during recording. This minimized time base errors. The output from the playback unit was converted to digital form and analyzed using a DEC LSI-I I digital computer. The data were analyzed to show the average pressure throughout the entire experiment and to count the number 
of lift-offs defined as a drop in pressure to below Io $\mathrm{mmHg}$. The time between each lift-off and the total experimental time was calculated. A hysteresis loop of Io $\mathrm{mmHg}$ was built into the computer program to prevent the data from oscillating in and out of the 'lift-off' region of pressure readings. A push-up was defined as pressure relief below Io $\mathrm{mmHg}$ with a duration greater than five seconds. If the push-up time was less than the selected duration, a relief of pressure was not recorded and the sitting time period continued to increase in duration.

\section{Results}

The average pressures for all subjects, the average experimental time, and the average time between push-ups on the two types of cushions studied are shown in Table I. The pressure under the ischial tuberosities on the cushions were $7 \mathrm{I} .5$ and $105.4 \mathrm{mmHg}$ on the ROHO and foam cushions respectively. This difference in pressure was of statistical significance $(\mathrm{p}<.05)$ using a two tailed student $\mathrm{T}$ test. If the results from the four runs on all subjects are combined, the average time duration between all push-ups I second was I hour and 8 minutes, and the average time between push-ups 5 seconds was 2 hours and I I minutes.

Figure I shows a typical pressure recording in a given individual. The temperature channel shows a gradual climb to near body temperature. The temperature remains fairly constant until the subject is transferred from his wheelchair to a bed. The pressure channels show some oscillation in pressure but only infrequent reduction of pressure to below IO $\mathrm{mmHg}$. Most of the pressure reductions occur immediately before the subject was transferred from the wheelchair to the bed.

Figure 2 depicts the time duration between push-ups of greater than 5 seconds and greater than I second for both the right and left ischial tuberosity. Although many push-ups took place within acceptable 20 minute periods, a very significant number of long periods without pressure relief existed. Many of the lift-offs done 'frequently' occurred early in the experiment when the subjects were getting comfortable in their chair, or late in the experiment when their weight was being shifted prior to transfer to bed for removal of the experimental equipment. The mean

TABLE I

Average pressures and push-up times

\begin{tabular}{|c|c|c|}
\hline & $\overline{\mathbf{x}}$ & $S x$ \\
\hline $\begin{array}{l}\text { Average Pressure (Rt and Lt tuberosity) on ROHO }(n=20 \\
\text { Average Pressure (Rt and Lt tuberosity) on Foam }(n=20)\end{array}$ & $\begin{array}{l}7 \mathrm{I} \cdot 5 \mathrm{mmHg} \\
\mathrm{IO5} \cdot 4 \mathrm{mmHg}\end{array}$ & $\begin{array}{l}26 \cdot I \\
64 \cdot 4\end{array}$ \\
\hline $\begin{array}{l}\text { Average Experimental Duration (ROHO) }(\mathrm{n}=20) \\
\text { Average Experimental Duration (Foam) }(\mathrm{n}=20)\end{array}$ & $\begin{array}{l}320 \mathrm{~min} . \\
34 \mathrm{I} \mathrm{min} .\end{array}$ & $\begin{array}{l}\text { I } 56 \cdot 0 \\
\text { I } 98 \cdot 7\end{array}$ \\
\hline $\begin{array}{l}\text { Average Time Between Push-up I sec. on ROHO }(\mathbf{n}=20) \\
\text { Average Time Between Push-up } 5 \text { sec. on ROHO }(\mathbf{n}=20) \\
\text { Average Time Between Push-up I sec. on Foam }(\mathbf{n}=20) \\
\text { Average Time Between Push-up } 5 \text { sec. on Foam }(\mathbf{n}=20)\end{array}$ & $\begin{array}{l}76 \mathrm{~min} . \\
\text { I } 6 \mathrm{~min} . \\
60 \mathrm{~min} . \\
78 \mathrm{~min} .\end{array}$ & $\begin{array}{l}\text { I } 31 \cdot 6 \\
\text { I } 69 \cdot 2 \\
\text { I } 46 \cdot 1 \\
\text { I } 63 \cdot 3\end{array}$ \\
\hline
\end{tabular}




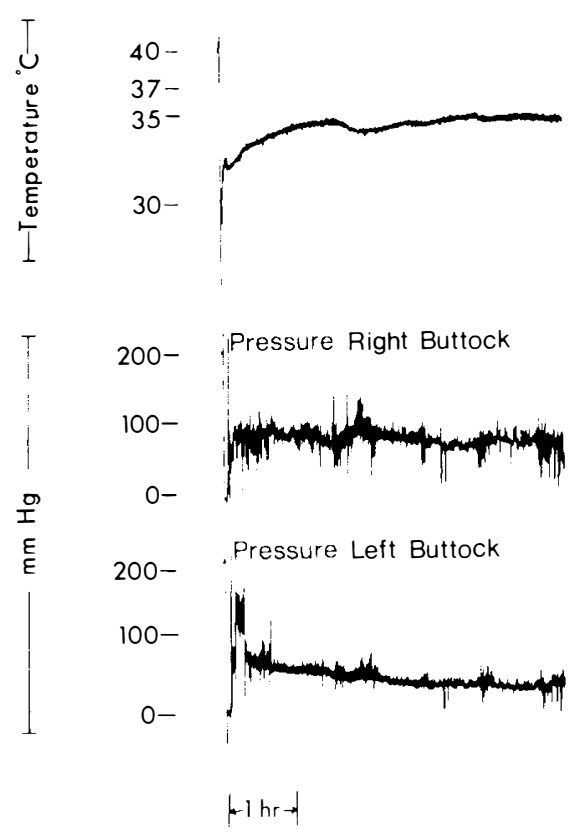

FIG. I

A typical pressure and temperature record from one subject recorded for 5 hours.

time between push-ups of $>$ I second and $>5$ seconds on the left tuberosity was I hour and 32 minutes and I hour and 59 minutes respectively and 52 minutes and I hour and I 4 minutes on the right (solid bar on Figure 2). If push-ups occurring during the first and last Io minutes are ignored, when subjects are 'getting comfortable' or preparing to be transferred, the mean time increases to 2 hours and 5 I minutes and 3 hours and 27 minutes on the left and I hour and 27 minutes and 2 hours and 3 minutes on the right (dashed bar on Figure 2). This information is also shown in tabular form on Table II.

\section{Discussion}

The difference in the average pressures between the ROHO and the foam cushion was statistically significant. This must be very carefully considered however since our subject population was small and since the problem of accurately measuring pressures over bony prominences has been documented (Patterson \& Fisher, 1979). The absolute value of the pressure measurements can be in error due to difficulty in placing the transducer on the skin exactly over the ischial tuberosity and because of the error inherent in the use of these transducers for soft tissue measurement. From data obtained in a previous study the estimated error is believed to be approximately i 5 per cent, but a given measurement could have a much greater error (Patterson \& Fisher, 1979). Even though there is error in determining the maximum pressure under the ischial tuberosities, a push-up near zero pressure is reliably determined in this study. 


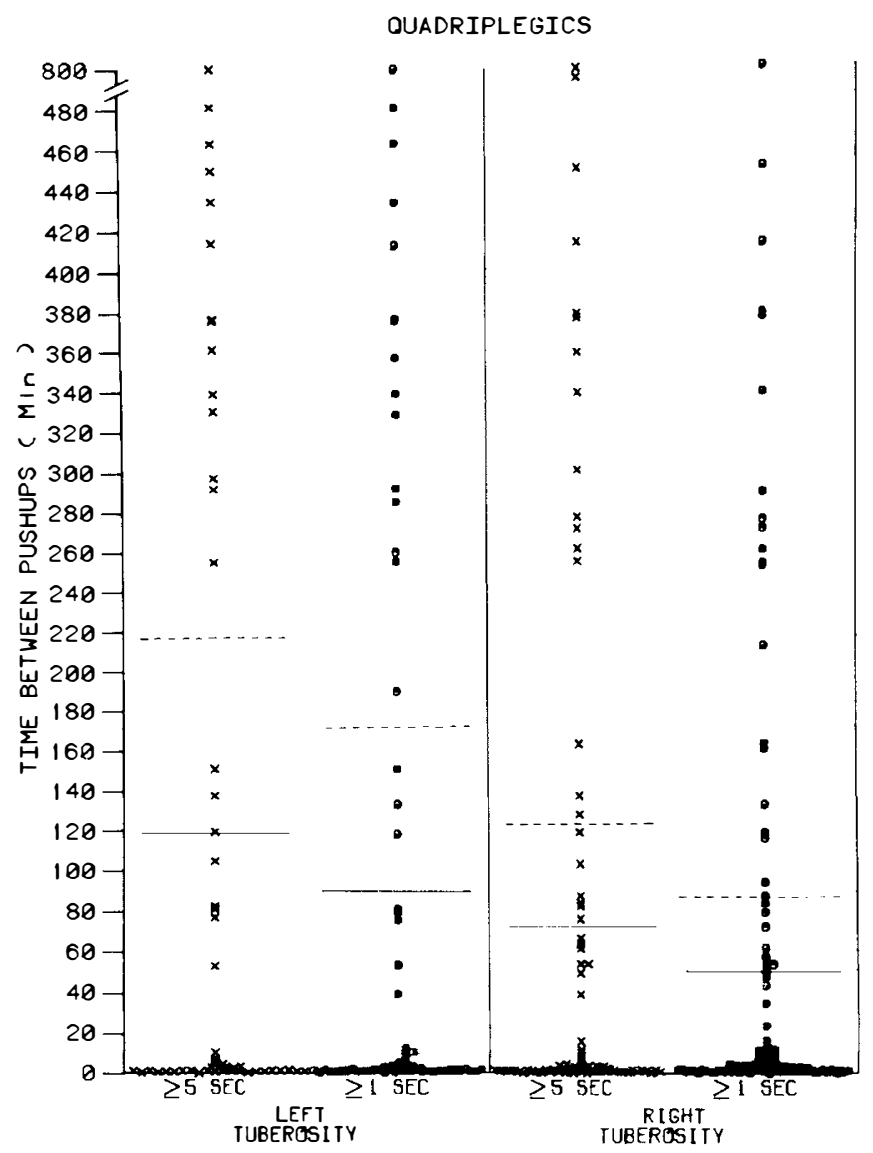

FIG. 2

Distribution of lift-off time intervals for the right and left tuberosity of five quadriplegic subjects each studied on four separate days.

Mean time between lift-offs. - - - - Mean time between lift-offs excluding the first and last io minutes of each experimental run.

TABLE II

Average pressures and push-up times

All lift-offs

\begin{tabular}{|c|c|c|c|c|}
\hline & \multicolumn{2}{|c|}{ Right tuberosity } & \multicolumn{2}{|c|}{ Left tuberosity } \\
\hline & $\overline{\mathbf{x}}$ & Sx & $\overline{\mathbf{x}}$ & Sx \\
\hline I sec. & $52 \mathrm{~min}$. & I I 7 & $92 \mathrm{~min}$. & I64 \\
\hline $5 \mathrm{sec}$. & $74 \mathrm{~min}$. & I 44 & I $19 \mathrm{~min}$. & I 84 \\
\hline \multicolumn{5}{|c|}{ First and Last io Minutes of Each Run Eliminate } \\
\hline I sec. & $87 \mathrm{mi}$ & I 37 & I 7 I min. & I93 \\
\hline $5 \mathrm{sec}$. & I23 min. & I 72 & $2 \mathrm{I} 7 \mathrm{~min}$. & 203 \\
\hline
\end{tabular}


The difference in the number of $>\mathrm{I}$ second or $>5$ seconds lift-offs on the foam and $\mathrm{ROHO}$ were not of statistical significance. There was no significant difference in the experimental duration comparing the $\mathrm{ROHO}$ and the foam cushions. The sitting behaviour of each subject from day to day remained relatively unchanged.

Each of these five subjects were studied on four separate days and far exceeded the suggested duration between push-ups as well as normally acceptable pressures. Yet, these subjects have no history of decubitus ulcers. The experimental days were felt to be typical days for these people. We must therefore assume that these subjects have many repeated daily bouts of long, uninterrupted pressure, of a duration thought to cause tissue damage.

In a recent study long periods without pressure relief did not cause decubitus ulcers (Newson et al., I98I). The partial pressure of oxygen in the skin was measured while applying pressure on the skin of healthy subjects. Although this study measured oxygen tension only in the skin and decubitus ulcers are known to be a full thickness injury, the pressures at which the partial pressure of oxygen became zero were significantly higher than the generally considered pressure limit for tissue viability.

Additionally, recent work has studied single applications of pressure in the development of pressure ulcers in pigs. Muscle damage without skin damage was noted with pressures of $100 \mathrm{mmHg}$ after IO hours. Full thickness damage involving muscle and skin were not seen until a pressure of $200 \mathrm{mmHg}$ was sustained for I6 hours (Daniels et al., I98I). It must be remembered however that although high pressures were needed over long periods to cause an ulcer, only a single ischemic insult was used. The authors felt that repetitive daily insult leads to progressive destruction of muscle and later of skin.

Certainly shearing and frictional forces must be considered important aetiological agents in the development of ulcers. Frictional force has been demonstrated to be an important factor in the development of decubitus ulcers of pigs (Dinsdale, I974). The combination of shearing and pressure has been shown to be particularly effective in occluding blood flow (Bennett et al., 1979).

There has been a recent demonstration that shear forces especially in the geriatric population have a very negative effect on blood flow (Bennett et al., I98I).

The pressure-time curves for paraplegics have previously been studied (Patterson \& Fisher, 1980) and found to be 'more acceptable' than the pressure-time relationships shown in this study for tetraplegics. The tetraplegics sat for longer periods of time between lift-offs than did the paraplegics. Additionally, the tetraplegics pressure records displayed less pressure oscillations. Most importantly, none of the tetraplegics in this study have had an ulcer.

From this study and those found in the literature, it can be theorised that the greater activity level of paraplegics compared to tetraplegics caused the increased number of oscillations seen in the paraplegic records (Patterson \& Fisher, 1980). It can be theorised that these oscillations represent repetitive frictional and shearing forces imposed on the skin under the ischial tuberosities. It is suggested that these forces add the additional repetitive stress to the skin compounding the insult from the static uniaxial 
pressure which in combination may finally cause skin necrosis.

The effect of repetitive pressure on the foot pads of anesthetised rats has been studied (Brand et al., I98I). Rats who were stressed and allowed 2 days a week for rest and healing of inflammation and blisters, developed hypertrophy of the epithelium and no tissue breakdown. The experiments showed that repetitive stress without rest periods for epithelial hypertrophy leads to an inflammatory state and finally ulceration.

It is theorized that the skin of spinal cord injured subjects can adapt over time to improve the skin's ability to withstand prolonged repetitive pressure and shearing forces. This theory requires further study.

\section{RÉSUMÉ}

Cette étude porte sur cing tétraplégiques sans plaies de siège. Aucun d'eux ne pouvait se soulever pour soulager les pressions sur les régions fessières. Les pressions sous les tubérosités ischiatriques ont été enregistrées pendant quatre journées consécutives sur deux types de coussins en caoutchou mousse. De petits transducterus de pression électriques et une enregistreuse ont servi a obtenir les résultats. Les pressions moyennes enregistrées sur le ROHO et sur les coussins en caoutchou mousse étaient de l'ordre de $7 \mathrm{I}^{\cdot} 5$ et 105.4 $\mathrm{mmHg}$ respectivement. Les manoeuvres a soulager la douleur étaient divisées en deux groupes; celles qui prenaient plus d'une seconde et celles qui prenaient plus de cinq secondes. La période écouleé entre chaque manoeuvre était de l'ordre de $72 \cdot 1$, et $96 \cdot 2$ minutes respectivement. Les pressions moyennes et la période écouleé entre les manoeuvres a soulager la pression dépassaient de beaucoup ce qui est habituellement suggeré comme routine pour la prévention des complications cutanés des tétraplégiques. Les résultats suggèrent que l'importance relative attachée à la pression et au soulagement de la pression devrait être revisée en fonction de son rôle dans l'étiologie des plaies de siège.

\section{ZUSAMMENFASSUNG}

In 5 Quadriplegikern die keine Hautulzerationen hatten, wurden an 4 verschiedenen Tagen die Drucke unter den tuberositae ischii gemessen. Zweierlei Sitzunterlagen wurden mit Hilfe von shmalen Druckmessern und einem Tonbandgeraet untersucht. Mit Roho Luftkissen die durchschnittlichen Drucke waren $71.55 \mathrm{~mm}$. Hg., mit Schaumgummikissen I05.4 mm. Hg. Die Zeitintervalle zwischen von den Patienten durchgefuehrten Druckverringerungen (push-ups) die laenger als eine Sekunde daunerten massen 72. I Minuten; solche von euber 5 Sekunden waren 96.2 Minuten. Durchschnittliche Drucke und die Zeitintervalle zwischen Druckverrigerungen ueberstiegen allgemein akzeptierte Normen.

Es scheint daher, dass die Bedeutung von Hautdrucken und den Zeitintervallen zwishchen Druckverringerungen in der Genese von Haut-und tieferen Ulzerationen neu undersucht werden meussen.

Acknowledgements: The authors would like to thank Marge Olson Ackerman, R. N. and Kathy Krueger, R. N. for their assistance.

\section{REFERENCES}

Bennett, L., Kavner, D., Lee, B. Y. \& Trainor, E. S. (I979). Shear vs pressure as causative factors in skin blood flow occlusion. Arch. Phys. Med. Rehabil., 60, 309-3I4.

Bennett, L., Kavner, D., Lee, B. Y., TrainoR, E. S. \& Lewis, J. M. (I98I). Skin blood flow in seated geriatric patients. Arch. Phys. Med. Rehabil., 62, 392-398.

BRAND, P. W., Sabin, T. D. \& BURKe, J. F. (I98I). Sensory denervation, final report, SRS Report N. RC-40-M, U.D. Dept. of H.E.W., Washington, D.C.

Daniel, R. K., Priest, D. L., Wheatley, D. L. (I98I). Etiologic factors in pressure sores: an experimental model. Arch. Phys. Med. Rehabil., 6o, 492-498.

Dinsdale, S. M. (1974). Decubitus ulcers: Role of pressure and friction in causation. Arch. Phys. Med. Rehabil., 55, 147-I 52. 
Griffith, B. H. (1963). Advances in the treatment of decubitus ulcers. Surg. Clinic North America, 43, 245-260.

Kosiak, M. (1959). Etiology and pathology of ischemic ulcers. Arch. Phys. Med. Rehabil., 40, 62-69.

Mooney, V., Einbund, J. J., Rogers, J. E. \& Stauffer, E. S. (i97I). Comparison of pressure qualities in seat cushions. Bul. Pros. Res. BPR, 10-1 5, I 29-1 43.

Newson, T. P., Pearcy, M. J. \& Rolf, R. (I98I). Skin surface $\mathrm{PO}_{2}$ measurement and effect of externally applied pressure. Arch. Phys. Med. Rehabil., 62, 390-392.

Patterson, R. P. \& Fisher, S. V. (I980). Pressure and temperature patterns under the ischial tuberosities. Bul. Pros. Res. BPR, 17, 10-34.

Patterson, R. P. \& Fisher, S. V. (I979). The accuracy of electrical transducers for the measures of pressures applied to the skin. IEEE transactions on BioMed Eng. BME, 26, $450-456$.

SOUTHER, S. G., CARR, S. D. \& VISTNES, L. (1974). Wheelchair cushions to reduce pressure under bony prominences. Arch. Phys. Med. Rehabil., 55, 460-464. 